\title{
Security Challenges in Nigerian Residential Real Estates.
}

\author{
${ }^{1}$ Olajide, S. E., 2Kolawole, A. O. (Surv.) \\ ${ }^{1}$ Dept. of Estate Management, Federal Polytechnic, Ado-Ekiti, Ekiti State, Nigeria \\ ${ }^{2}$ Dept. of Surveying \& Geo-Informatics, Federal Polytechnic, Ilaro, Ogun State, Nigeria
}

\begin{abstract}
It is an understatement that security remains one of the principal challenges bedeviling the nation . Real estate as a matter of fact is no exemption. Hence, this paper attempts to consider security challenges as they affect residential real estate in Ado Ekiti, Ekiti-State. The systematic sampling technique was adopted on Adamolekun estate (private) and Irewolede estate (public). Results of findings showed that individual efforts were more pronounced in the area of providing adequate security. The authors concluded by recommending that government should do something substantial to compliment the private efforts, by encouraging community and neighbourhood policing in residential real estate in order to ameliorate security challenges in Nigeria.
\end{abstract}

Keywords: Ado-Ekiti, challenges, Residential, , Real estate, security,

\section{Introduction}

Security in developed and developing nations is a non-negotiable in any residential Estate. Whether it is access control at the gate, electric fencing with cameras or guards patrolling, families living in these complexes feel secured in the knowledge they are protected against almost any calamity. But how secured are these estates really? Downing (2007) warned that the security many people rely on to protect their homes and families may in fact not be as good as they would wish." It is not that the products used are of poor quality, or even that the companies retained to handle various security function cannot do the job", explained Downing. "The problem according to him is that Estates hire different companies to handle different aspects of their security. And while each company may be an expert in its field there is no integration between the various disciplines".

In other words, the importance of keeping a home, its occupants, and its valuables safe and secure cannot be overstated, yet the challenges of effective security strategies can be time- consuming and stressful for some homeowners. Though some may choose to work through this difficulties and develop home security measures on their own, others may find it preferable to work with a professional company that specializes in preventing and responding to burglaries and other potentially damaging events (Seldon, 2007).

Essentially, how safe a house is not just about keeping people out of your house. It is about protecting the things that are valuable to you, including your children, personal information and identities, valuables and all of the things that matter most to you.

Agbola (1997) argued that looking around Nigerian Cities, one would notice the general trend towards the construction of high walls around residential units, which have become so high that they obstruct the visual beauty of such buildings, sometimes concealing them altogether, erection of houses which are intricately shielded with burglary proofing, construction of massive gates and strong locks, installation of lighting facilities at every corner of the residential environment, and a host of other protective devices, all of which give credence to the assertion that city architecture in Nigeria today is governed by the fear of incursion by robbers. The cost of all these measures, whether social, environmental, and/or monetary and the extent to which they have reduced crime, are all issues worthy of empirical investigation.

Considering home security system, this ranges from simple to sophisticated. This has to do with the level of development, economic ability of the home owner or house user. Over the years, various systems have been used to provide security for the home. This include, Vigilante, trained dogs, high fencing, charm, thermal cameras, alarm systems, fire wire, surveillance tools and wire, spy gear, fire alarm, home automation, temperature sensor, water and floor sensor, video recorder, CCTV monitors and likes. It needs to be mentioned here that most of the sophisticated home security systems are still not common in Nigeria due to the cost of procurement, complexity in installation and use, and unplanned nature of most our residential environments.

It needs to be mentioned at this juncture that issue of home security must be handled with dispatch as it determines the emotional stability of the citizens which transform to the determination of their efficiency as this also add or reduce the Gross Domestic Product of the nation.

According to Agbola (1997) Violence and crime are a huge threat to public safety. They cause great personal suffering, vast material damage, and place enormous burden on the urban social network. Yet, as Vanderschueren (1996) observed, urban violence has increased worldwide in the last decade at a rate which has largely surpassed that of urbanization. Globally, every five years, 60 per cent of city inhabitants have been 
victims of one form of crime or the other and over half of these crimes have involved properties- home insecurity.

The efficiency of labour of the working class has much bearing on their emotional stability which can be determined by how secured the residential estates are. All these will borne down to determining the buoyancy of the economy. Hence, the dire need to look into the challenges confronting residential estates in Nigeria in general and Ado-Ekiti in particular with a view to proffering sustainable coping measures.

\section{Theory Of Defensible Space - An Alternative To Fear}

Defensible space is a theory of crime developed by Oscar Newman in his seminal study of public residential buildings in New York. Newman's goal was to present a model for residential environments which would inhibit crime by creating the physical expression of social fabric that defends itself. In simpler terms, he attempted to solve the problem of getting a person to and from his or her living quarters without the fear or occurrence of crime. His first preoccupation was to study the physical characteristics of housing projects, to determine which of these might present an opening for criminal activity.

He first observed the large open spaces around project buildings, often designed for recreation and leisure. Since these areas are situated away from traffic, they become the most vulnerable part of the building project, because even at the peak of daily activities, their detachment makes them a no-man's-land; they are avoided at night because they provide opportunities for criminal violence without observation. Another observation was about high-rise buildings with long corridors that have exits on both ends, several elevators, and fire escape routes which could provide a criminal with multiple escape routes. The scale of a building project could be a problem by itself (Newman, 1978). For example, the larger the number of units, the less the ability of the residents to recognized stranger; they thus become less involved in the control of the area surrounding the project. Moreover, the social stigma associated with public housing projects encourages a feeling of isolation in their residents. This stigma is like a flag that invites exploitation by criminals.

In correcting these observed anomalies in building design, Newman suggested the 'defensible space model' to discourage attempt by criminals to commit crimes. He presented the concept of defensible space as a surrogate term for a range of mechanisms-real and symbolic barriers, strongly defined areas of influence and improved opportunities for surveillance- that combine to bring an environment under the control of its residents. A defensible space, therefore, is defied a residential environment which can be employed by inhabitants to enhance their living conditions, while providing security for their families, neighbours, and friends.

Defensible space, in term of the arrangement of building grounds and the interior grouping of apartments is achieved when residents can easily observed and control all activities taking place within it. Residents can then be seen to employ a full range of encounter mechanisms which show their observation of questionable activity and their control of the situation. The criminal, on the other hand, will perceive the space as being controlled by its residents, thus exposing him as an intruder who can be easily recognized and dealt with. The defensible space or environment extends into the street which surrounds the residence. There are four elements of physical design that contribute, separately or jointly, to the creation of secure environments. These are: territorial ownership, natural surveillance, image and milieu, and functional location of buildings

\section{Literature Review}

Research on the different aspects of home security and other associated issues has been the almost exclusive preserved of Sociologists Political Scientists, Criminologists, and Penologists. Over time, as urban residential real estate insecurity has become more endemic and its effects more pervasive, social and environmental scientists have become interested and involved in the nature, causes, consequences and solution to urban residential insecurity. Urban planners, architects, real estate surveyors, etc have become active researchers in the field of residential real estate insecurity; especially as it relates to and effects human psychology and general economy.

Effort is however harnessed below to appraise various studies as they discuss on the subject matter.

\subsection{Doctrine Of Residential Real Estate}

Thorncroft (1978) defined estate as not necessarily the physical structure but the quantum and quality of right and control the owner has the ability to exercise. He also sees it to include the length of time the user has over the land. Hence, he was able to identify two major classes of an Estate - Freehold and Leasehold. Freehold means the right to hold over or on land in perpetuity while Leasehold estate represents ownership with time certain.

Olajide et al (2003) expressed residential real estate as buildings that are basically or essentially used for the purpose of providing living accommodation. These according to them are categorised by density- Low, High or 
Medium; design- bungalow, flat tenement, Duplex, semi-detached, mansion etc; settlement-rural, semi-urban and urban. The other name for residential Estate is Housing.

Johnson et al (2000) see residential estates to include area of property which touches on most people in their everyday lives. The range of properties is vast, with tenements and cottages at one extreme and country estate at the other. They also see it as the area of property which is most affected by legislation because of the perceived need to protect the individual against exploitation. They identify the follows as common factors that determine the value of residential estate - location, position, physical characteristics and general economy to mention only but a few.

\subsection{Home Security}

According to Agbola (1997) in his work titled 'Architecture of fear', it was revealed that looking around Nigerian Cities, one would notice the general trend towards the construction of high walls around residential units, which have become so high that they obstruct the visual beauty of such buildings, sometimes concealing them altogether, erection of houses which are intricately shielded with burglary proofing, construction of massive gates and strong locks, installation of lighting facilities at every corner of the residential environment, and host of other protective devices, all of which give credence to the assertion that city architecture in Nigeria today is governed by the fear of incursion by robbers. He posited that this action or attitude inferably is an invitation to the robbers that they (occupants) have something precious to steal. Over the years, this so called "architecture of fear" has caused untimely death of many families in Nigeria as going by the nature of design whenever there is problem of inferno mostly in the night, rescue always become impossible. He concluded by recommending that neighbourhood associations should be encouraged while residents should be more security conscious and organized vigilante groups. In addition, Agbola (1997) suggested as a matter of urgency that planner and urban designer s should endeavour to be security conscious in the planning and design of residential neighborhoods while keeping general environmental health and accessibility in view.

Considering the seriousness attached to the Residential real Estate Security, Siciliano (2010) proffered ten (10) home security tips one may never thought of which include.

3.2.1 Get a life -size cardboard cutout of yourself and put it a ten feet away from a window that gives the impression someone is always home.

3.2.2 Get another life-size cutout of you lying on the couch watching TV and keep the TV on while you are gone

3.2.3 Find a Talk AM radio station and keep it on LOUD all day and night while you gone

3.2.4 Plant defensive shrubs or thorny bushes around basement or ground- floor windows that make it difficult for the bad guy to get through.

3.2.5 Buy and install a "This property is protected with VIDIO SURVEILANCE" sign.

3.2.6 Get 2 big dog food bowls and write KILLER on them and put them on your front and back porch.

3.2.7 Whenever you leave the home turn phone ringers down or off so the bad guy won't hear ringing and ringing and ringing when you're not home

3.2.8 Set your answering machine to say "Sorry I can't answer the phone right now, I' m busy cleaning my guns, leave a message and I'll call you back once they are all loaded again.

3.2.9 Pick up a home alarm that sense when someone giggles your door handles. These alarms will send off a siren or they will play a recording of a barking dog.

3.2.10 Get out and buy, then install "POLICE CRIME SCENE DO NOT CROSS" tape on your front and back door or porch giving the impression something bad HAS happened. Not only will your neighbours pay serious attention to it, they'll most likely call you and you can tell them to watch your house. Plus any bad guys will steer clear of your home.

Mimiko (2012) suggested among other things that the resurgence of incessant criminal activities on people and property in some parts of the country could only be effectively curbed if Nigeria embraces the practice of true federalism. He asserted that enough federalism would encourage devolution of powers from the Federal Government to state and local councils and would guarantee effective policing. Mimiko lamented the extent of carriage and destruction of valuable private and public property, stressing that perpetrators and their sponsors would have been identified and arrested if the security agent on their trail were members of their community. He is actually soliciting for state and community police as a panacea to social crime. This however has received public discussion.

One of the most popular types of professional home security assistance is home alarm monitoring, which may employ any number of devices and policies to keep a residence safe. Understanding how this service operates and knowing what makes a great monitoring company can lead to a satisfying security decision that deliver both value and peace of mind (Hannah, 2011). She believes that modern home security equipment can go a long way towards fending off potential criminals and thwarting any actual invasion or damage attempts. The specific equipment that an individual home security alarm monitory service uses is a big part of its offering, 
and the types of products available should be reviewed and discussed before agreeing to a monitoring plan. Alarm may be installed to cover doors, windows and other entry points around the home, but may also rely on movement detection to signal any kind of movement in or near the house. The only impediment is the cost of procurement which run to average of half a million naira without considering the cost of transportation and associated taxes.

Consequently, Azuh (2012) wrote on unique affordable home security gadgets that can keep burglars away. He emphasized that most people who have had an encounter with burglars or armed robbers never forget the experience. Usually, the encounter leaves a chilling impression on their minds. Unfortunately, some believe that only the very rich can keep the burglars away with expensive security gadgets. He poised that it is not entirely true. While there are actually some very expensive home security gadgets, there are others that are equally affordable as well as effective- if not more effective than the expensive ones. He considered door stop alarm as one of the most effective low cost home security gadget. According to coolestgagets.com, when placed against a door, the door stop wedges underneath it and prevents it from opening. Further when a burglar tries to enter. In addition the alarm sounds and emits powerful 120-decibels to warn the occupants and dater the burglar. He also mentioned camera home security system which is equally known as fake home security camera. According to homesecuritysystem.org, it is a proven fact that even a fake home security camera can deter criminals and act as a significant addition to a home security system. It feature a blinking LED light and side-toside surveillance motion. It's presence can enhance home security. All it takes is to mount one at an easily detectable spot in or outside the home. He emphasized that this system function like the closed-circuit television or CCTV. Other cheap security system identified by him includes the stickers and home security yards sign, the mini magnetic contact alarms, combination lock and electronic watch dog.

In the work of Olaniran (2006) it was pointed out that security issues as they are attached to the home has come misconception. He argued that security in the home goes beyond providing for the safety of life and properties but also extent to the preservation of the environment in general and the building in particular. This includes prevention of erosion and floor, prevention of fire outbreak, protection of children, flexibility in design to guide again building obsolescence and the like. He believes that when all these are taken into account, home security would be given the serious attention it deserves by the homeowner and especially the government.

\subsection{Home Security And Residential Property Value}

Olajide (2010) established that one of the basic factors that determine property values especially residential, is the reliability of physical security of the neighbourhood as well as that of the property. He argued that residential estates that are prone to robbery attacks usually suffer reduction in both capital and rental values. In his findings, he further discovered that the rate of turnover of properties suffering from inadequate security is usually low thereby rendering such properties unattractive and unprofitable. Onifade (2007) in his view believes that it is not only robbery incident that constitutes home insecurity but incessant neighbourhood unrest, urban violence, noise pollution and high vehicular traffic among others. All these he affirmed will negatively affect residential real estate market.

\section{Methodology}

The use of structured questionnaire was adopted. The questionnaire were administered on the occupants of both private and public estates. That is, Adamolekun Estate and Irewolede Estate respectively. A total of 30 questionnaire were administered each on the estates. The sample size of 30 was considered adequate through the use of systematic sampling technique. Data were presented and analyzed through the use of tables, charts and the use of other descriptive statistics.

Adamolekun estate is located along Adebayo/Opopogboro going to Ekiti State University. It was developed by Late business man Late Pa. Adamolekun. The Estate comprises of 43 units of flats of different designs. Irewolede Estate on the other hand is located along Ilawe Road, adjacent to Federal Polytechnic AdoEkiti Centre for Continuing Education. It is made of about 150 units (Development on-going) of different designs. It was built by the Ekiti State government through the use of National Housing Fund scheme.

\subsection{Data Presentation And Analysis}

Apart from the personal interview and survey to the studies areas, structured questionnaire was drafted and administered upon which the following analysis were made.

Table 1: Frequency of Robbery cases

\begin{tabular}{|l|l|l|}
\hline Particular & Frequency & Percentage (\%) \\
\hline High & 40 & 71.4 \\
\hline Low & 14 & 25.0 \\
\hline None & 2 & 3.6 \\
\hline Total & 56 & 100 \\
\hline
\end{tabular}


Source: Field survey, 2012

From table 1 above, it is evident that there is high frequency of robbery attacks in the city of Ado-Ekiti because the percentage shows $71.4 \%$ high. This calls for urgent attention.

Table 2: Frequency of Power supply

Source: Field survey, 2012

\begin{tabular}{|l|l|l|}
\hline Particular & Frequency & Percentage (\%) \\
\hline Very Regular & o & 0.0 \\
\hline Regular & 1 & 1.8 \\
\hline Often & 10 & 17.9 \\
\hline Scarcely & 37 & 66.1 \\
\hline None & 8 & 14.2 \\
\hline Total & 56 & 100 \\
\hline
\end{tabular}

Above table (Table 2) shows that Electricity supplies in most of the Estate were scarcely provided. None could choose very regular, meaning that much has to be done in this respect.

Table 3 : METHOD OF SECURITY SYSTEM

\begin{tabular}{|l|l|l|}
\hline Particular & Frequency & Percentage (\%) \\
\hline Burglary Proof & 50 & 89.3 \\
\hline Fencing & 30 & 53.6 \\
\hline Guards & 4 & 7.1 \\
\hline Vigilante & 15 & 26.8 \\
\hline Security Dogs & 17 & 30.4 \\
\hline Alarm System & 2 & 3.6 \\
\hline Surveillance & 4 & 7.1 \\
\hline Closed circuit Television & 1 & 1.8 \\
\hline Others & 10 & 17.9 \\
\hline
\end{tabular}

Source: Field survey, 2012

Table 3 above shows that majority of the residents depend on burglary proof and perimeter fencing as their major source of security. The modern use of Technology like the Alarm and Close circuit Television not popular. This might be as a result of poor supply of Electricity. The others come under use of charm and lighting. There are multiple choices.

Table 4: Who is to provide security

\begin{tabular}{|l|l|l|}
\hline Particular & Frequency & Percentage (\%) \\
\hline Government & 52 & 92.9 \\
\hline House owner & 12 & 21.4 \\
\hline House User & 14 & 25.0 \\
\hline Tenant & 15 & 26.8 \\
\hline Indifferent & 2 & 3.6 \\
\hline
\end{tabular}

Source: Field survey, 2012

Table 4 above, shows that the majority (92.9\%) of the respondents indicated that Government owes the greater responsibility to provide security. This may be so considering the enormous cost involved. There is multiple choices.

Table 5: Fence Type

\begin{tabular}{|l|l|l|}
\hline Particular & Frequency & Percentage (\%) \\
\hline Barbed Wire & 4 & 7.1 \\
\hline Block/ Concrete wall & 21 & 37.5 \\
\hline None & 29 & 51.8 \\
\hline Other (plank) & 2 & 3.6 \\
\hline Total & 56 & 100 \\
\hline
\end{tabular}

Source: Field survey, 2012

The implication of table 5 is that home owners are either not conscious of the need to provide security or the high cost of putting it in place. 
Table 6: Effect of residential estate insecurity on property values

\begin{tabular}{|l|l|l|}
\hline Particular & Frequency & Percentage (\%) \\
\hline Positive & 01 & 1.8 \\
\hline Negative & 54 & 96.4 \\
\hline Indifferent & 01 & 1.8 \\
\hline Total & 56 & 100 \\
\hline
\end{tabular}

Source: Field survey, 2012

Table 6 above shows that insecurity in residential estates would have negative effect on the values of the properties. This calls for quick response from the Agencies concerned.

\subsection{Summary Of Findings}

Having administered and analyzed the questionnaire, the following form the summary of findings.

4.2.1 Research findings showed that there is high occurrence of robbery within the residential neighbourhoods in Ado-Ekiti. This could be as a result of high rate of urbanization vis-à-vis uncontrolled upsurge of unemployment.

4.2.2 Government participation in the provision of security in the residential apartment was very low. Where police were supposed to be on guard (Irewolede Estate) research showed that they were not found.

4.2.3 General observation on the residential neighbourhood planning within the metropolitan city of Ado-Ekiti is Substandard. The relevance of the planning Authority seems not to be noticed. Houses germinate anyhow without following any building regulation.

4.2.4 Use of modern security system in the homes was obviously absent due to ignorance, epileptic power supply and high cost of procurement, among others.

4.2.5 It was also observed that there was not good cooperation among residents. Every resident appears like a lone-ranger. This has actually affected the sensitivity of the residents to crime.

4.2.6 The effect of residential insecurity on property values. From the findings, it was shown that the values ( capital and rental) of property within the residential neighbourhood prone to insecurity or incessant disturbance, crime and robbery would be negatively affected, in that their values would be reduced due to low patronage. Fom the survey conducted $96.4 \%$ of the respondents agreed to this.

4.2.7 Generally speaking, the challenges confronting residential Estate in the area of security are enormous and the prospect as to ameliorating them is shallow. This also manifested in virtually absence of Land Information System in respect of Land within Ado-Ekiti territory as the capital city. Approved comprehensive master plan was found to be invisible.

\section{Recommendations}

In order to improve on the effort on ground in the area of home security, the following measures are proffered ;

5.1 Need for proper planning of residential neighbourhoods. In Ado-Ekiti the way and manner private estates are built reflects element of poverty. Buildings are built without planning approval and without the essential housing facilities. All these make the house prone to attack and invasion. Urban planners are implored to expedite action on approval of building plan to enhance standardization.

5.2 Government collaborative efforts. Security issues cannot be discussed in isolation. There is need for the public private partnership concept to come to play. The private sectors are to provide necessary facilities that will make their home safe to a great extent while the government on the other hands is expected to provide good road within and around residential neighbourhood, stable power supply and provision of Neighbourhood police. 5.3 Publication of policy statement by Government on residential building standardization. Government is expected to make policy statement as touching the minimum requirements of a house and its neighbourhood.

5.4 The need to revamp the economy. Provision of employment for the looming population has been variously seen as a practical antidote to the alarming rate of neighbourhood crime.

5.5 Need for sincere discipline of corrupt law enforcement Agents. Machinery must be put in motion to curb corruption among the police especially and other law enforcement agencies in general. However, our policemen must be well armed to be able to meet in contemporary challenges.

5.6 Use of modern security systems. This can be done through adequate enlightenment. As it has been argued it is not all of the systems that are expensive, some have been proven to be cheap and effective.

5.7 Need for sensitivity of dwellers. Residents are advised to put on eagle eyes in order to detect strange faces within the residential neighbourhood. Treatment of sacred cows must be discouraged. 
5.8 ICT empowerment through Land Information System. When our residential neighbourhoods (at least in urban centres) are well planned, there must be data bank in respect of all the land within the urban centers. Citizen should also have means of identification of which when crime is committed one can be easily identified. This is indeed a big minus to Nigerian Security System and credence to our high level of underdevelopment.

\section{Conclusions}

From the foregoing, it has been proven that issues relating to home security are non-negotiable. This is so because of the multiplier effect it can have on the general economy as when people (especially the working class) begin to experience emotional disturbance through robbery attack in the home, this will definitely reduce their efficiency of labour. Another point worthy of mentioning is the lackadaisical attitude of government toward complimenting the effort of the private sector in ensuring home security. Government is expected to provide stable power supply to scare criminals, good road system/network as well as community policing. The landlord or residents Association in the studied areas should be strengthened to scare away unwanted strangers and criminals.

Conclusively, the developmental progress about the effectiveness of home security in Ado-Ekiti is substandard and unacceptable. There is still much needed to be done in order to make our residential neighborhoods' places where occupant can sleep with their two eyes closed and even when they are out of home, their valuables remain intact.

\section{References}

[1] Agbola T. (1997) Architecture of Fear, Published Research Mimeograph. IFRA, Ibadan. Pp2-3, 119

[2] Azuh, M. (2012) Safeguard your home with affordable security system. Published in Punch Newspaper February $21^{\mathrm{s}}$.

[3] Downing I. (2007) Centralized Integrated Security optimal for Residential Estate. i to i Technology,South Africa, Internet.

[4] Hannah G. (2011) Professional Home Security Monitoring. Internet.

[5] Johnson, T, Davis, K \& Shapiro, E. (2000) Modern Methods of Valuation of Land, Houses and Buildings. Estate Gazette, London Pp 295-340.

[6] Mimiko O. (2012) True Federalism, Panacea to Security Challenges in Nigeria. Being paper presented at $9^{\text {th }}-$ Yoruba Youth Conference held in Akure, June 25.

[7] Newman, Oscar (1978) Defensible Space. Crime prevention through Urban Design. Macmillan, New York

[8] Onifade, F. A. (2007) Estate Security. Unpublished Lecture notes on Property Management. The Federal Polytechnic, Ilaro, Ogun State, Nigeria.

[9] Olajide, S. E. (2010) Critique of Residential Property Values in a developing Economy. Lecture mimeograph on Advanced Valuation. Fedpolyado. Pp. 7

[10] Olajide S.E. \& Bello I.K (2003) Element of Property Valuation. Campus Publication Ltd Lagos. Pp. 87-90

[11] Olaniran M.O. (2006) Nation-Wide Property Identification and Land Registration as basis for Sustainable Reform, Growth and Safety. ENVIRON-LINK Journal Vol.1 No2, School of Environmental Studies, Federal Polytechnic Ado-Ekiti, Ekiti State Pp 114.

[12] Seldon, Andrew (2007) Home Security Challenges. Internet. www.homesecuritystore.com Pp1959

[13] Siciliano, R. (2010) Tips on Home Security Posted in Heme, Home Security TIPS, House. Internet.

[14] Thorncroft M. (1978) Principles of Estate Management, Estate Gazette Ltd London. Pp. 2-4

[15] Vanderschueren, F. (1996) URBAN Violence, Justice and poverty. Habitat Debate pp 350-360. 